\section{Concrete Research}

The Magazine of Concrete Research is published periodically by the Cement and Concrete Association at Wexham Springs, Stoke Poges, Bucks., and the March issue $(14$, No. 40; 1962) contains, besides seven technical papers, an editorial on the future of prestressed concrete based on a lecture given by R. E. Rowe (in charge of research into structural design at the Cement and Concrete Association), earlier this year. Among the significant observations made by that author were the possibility of achieving concrete cube strengths of $12,000-14,000 \mathrm{lb}$./in. ${ }^{2}$ under closely controlled conditions of compaction and euring; the importance of specifying design stresses in concrete appropriate to the stress field in which it was required to function; consideration of possible biaxial or triaxial stresses and not simply uniaxial compressive strength as sole criterion of ultimate strength; the practical importance of the strength/ density ratio in prestressed concrete in future; the production of expansive cements and their scope in factory manufacture of precast units. Rowe also emphasized the fact that ". . . knowledge of the true failure criteria of concrete was still very limited. Future research would undoubtedly increase our knowledge, and lead to a revision of our ideas of permissible and ultimate load stresses. The informa. tion we already had suggested that this would mean higher values for these stresses". The other subjects traversed in this issue are reinforced concrete under thermal gradients; behaviour and ultimate strength of prestressed concrete hollow beams under combined bending and torsion; dynamic loading of prestressed conerete beams; deformation of a rectangular slab with free edges under transverse loads; triaxial testing of fresh concrete; studies of pore size distribution in mortars; and strength tests on scaleddown concretes suitable for models with a note on mix design. It may not be generally realized that the Cement and Concrete Association provides, on request, a free service of technical information and advice on all aspects of concrete construction by a highly experienced advisory staff. The Research and Development Services of the Association includes in its activities the making and testing of structural models, for example, the Hammersmith Flyover, the Medway Bridge, etc. It has available a Sirius elec. tronic computer for structural calculations and data processing; it also specializes in production of small specimen surface finishes to assist architects, engineers and others in developing methods of improving the appearance of concrete.

\section{United Kingdom Postgraduate Awards, 1962-64}

THE Association of Universities of the British Commonwealth has now issued its 1962-64 list, United Kingdom Postgraduate Awards. Primarily the purpose of this booklet is to set out in a form suitable for quick reference summarized information about fellowships, scholarships, grants, otc., tenable at universities in the United Kingdom. There is also appended a short list of awards tenable overseas by graduates from the United Kingdom. In the first section, information is supplied under the headings of the universities concerned-details being given of the subject of the award, its value, the length of time for which it is tenable, eligibility, number, closing date for application and details of where further particulars can be obtained. Similar treatment is given in the following sections, which deal with agriculture and veterinary science, applied science and technology, arts, dentistry, education, law, medicine and surgery, and science (specific subjects); the list is completed with a useful index of names. Copies can be obtained from the Association of Universities of the British Commonwealth, 36 Gordon Square, London, W.C.1 (5s., plus $6 d$. postage).

\section{The Hospital Library in Sweden}

IN Library Association Pamphlet No. 23 are collected translations by Mr. and Mrs. Frykman of a symposium of five papers on the hospital library in Sweden originally issued by the Swedish Library Association in 1958 (The Hospital Library in Sweden. Pp. 40. London: Library Association, 1962. 10s.; L.A. members, 7s. 6d.). The papers deal with the administration and organization of the hospital library; the principles of book selection for hospital patients; technical aids for the hospital library and patients; reading therapy in the service of the sick; and some personal reflexions on patients, doctors and books. The new technical aids are illustrated and some indication is given of the cost of the services recommended. The pamphlet gives a valuable indication of the possibilities and of the standards that could reasonably be expected, but it is also a notable contribution to constructive thinking on this general theme.

\section{The American Society for Metals}

Dr. Robert J. Raudebaugh, of Plainfield, New Jersey, was elected president of the American Society for Metals at the annual meeting of the Society held recently at the Hotel Biltmore. Dr. Raudebaugh, who is supervisor of Iron Nickel Alloys, Product Development of the Development and Research Department of the International Nickel Co., Inc., Now York, succeods Dr. Carl E. Swartz. Other officers and trustees of the Society who were elected at the same time, and who with Dr. Raudebaugh will take office, are: Vice-President, Merrill A. Scheil, director of Metallurgical Research, A. O. Smith Corp., Milwaukee, Wisconsin ; Secretary-Trustee, 1962-64, Dr. Stewart G. Fletcher, vice-president-technical director, Latrobe Steel Co., Latrobe, Pennsylvania; Trustees, 1962-64, Dr. Robert F. Thomson, technical director, Engineering Research, Research Laboratories, General Motors Corporation, Detroit, Michigan; Dr. Alexander R. Troiano, professor and head of Department of Metallurgical Engineoring, Case Institute of Technology, Cleveland, Ohio.

\section{Applications of Engineering in Medicine and Biology}

THe Leverhulme Trust has made available, each year for five years as from September 1963, four Leverhulme Bursaries, each of value $£ 1,000$ plus Federated Superannuation Scheme for Universities and National Health Insurance allowances, to enable persons engaged in medical or biological research to attend the postgraduate course in "Applications of Engineering in Medicine and Biology" which is in operation in the Department of Electrical Engineering, Imperial College of Science and Technology. The first annual course commenced in October 1962, and these bursaries will therefore be available for the course commencing in October 1963 and for subsequent courses. The courses are planned to meet the needs of present or intending research workers, qualified in medicine or biology, who require for their research a basic understanding of and familiarity 